
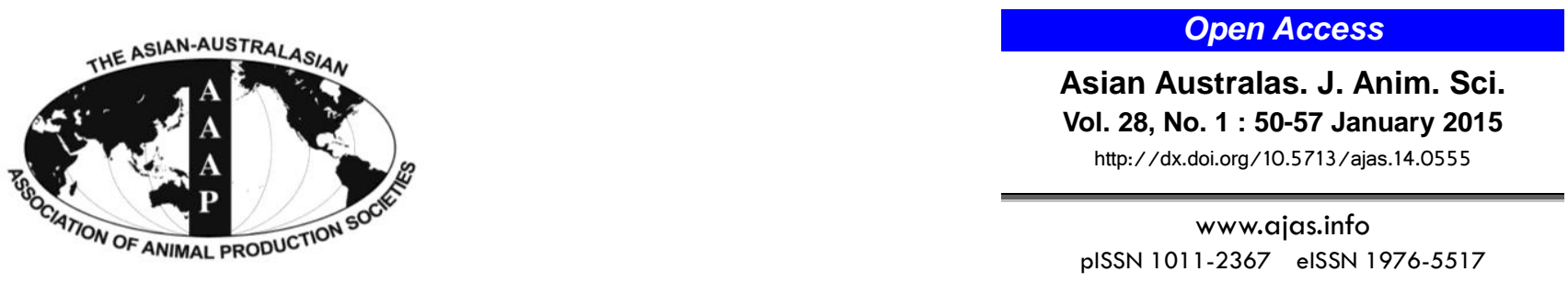

\title{
Effect of Soybean Meal and Soluble Starch on Biogenic Amine Production and Microbial Diversity Using In vitro Rumen Fermentation
}

\author{
Chang-Dae Jeong, Lovelia L. Mamuad, Seon-Ho Kim, Yeon Jae Choi, Alvin P. Soriano, \\ Kwang Keun Cho', Che-Ok Jeon ${ }^{2}$, Sung Sil Lee ${ }^{3}$, and Sang-Suk Lee* \\ Ruminant Nutrition and Anaerobe Laboratory, Department of Animal Science and Technology, \\ Sunchon National University, Suncheon 540-742, Korea
}

\begin{abstract}
This study was conducted to investigate the effect of soybean meal (SM) and soluble starch (SS) on biogenic amine production and microbial diversity using in vitro ruminal fermentation. Treatments comprised of incubation of $2 \mathrm{~g}$ of mixture (expressed as 10 parts) containing different ratios of SM to SS as: 0:0, 10:0, 7:3, 5:5, 3:7, or 0:10. In vitro ruminal fermentation parameters were determined at $0,12,24$, and $48 \mathrm{~h}$ of incubation while the biogenic amine and microbial diversity were determined at $48 \mathrm{~h}$ of incubation. Treatment with highest proportion of SM had higher $(\mathrm{p}<0.05)$ gas production than those with higher proportions of SS. Samples with higher proportion of SS resulted in lower $\mathrm{pH}$ than those with higher proportion of SM after $48 \mathrm{~h}$ of incubation. The largest change in $\mathrm{NH}_{3}-\mathrm{N}$ concentration from 0 to $48 \mathrm{~h}$ was observed on all SM while the smallest was observed on exclusive SS. Similarly, exclusive SS had the lowest $\mathrm{NH}_{3}-\mathrm{N}$ concentration among all groups after $24 \mathrm{~h}$ of incubation. Increasing methane $\left(\mathrm{CH}_{4}\right)$ concentrations were observed with time, and $\mathrm{CH}_{4}$ concentrations were higher $(\mathrm{p}<0.05)$ with greater proportions of SM than SS. Balanced proportion of SM and SS had the highest $(\mathrm{p}<0.05)$ total volatile fatty acid (TVFA) while propionate was found highest in higher proportion of SS. Moreover, biogenic amine (BA) was higher $(\mathrm{p}<0.05)$ in samples containing greater proportions of SM. Histamines, amine index and total amines were highest in exclusive SM followed in sequence mixtures with increasing proportion of SS (and lowered proportion of SM) at $48 \mathrm{~h}$ of incubation. Nine dominant bands were identified by denaturing gradient gel electrophoresis (DGGE) and their identity ranged from $87 \%$ to $100 \%$ which were mostly isolated from rumen and feces. Bands R2 (uncultured bacterium clone RB-5E1) and R4 (uncultured rumen bacterium clone L7A_C10) bands were found in samples with higher proportions of SM while R3 (uncultured Firmicutes bacterium clone NI_52), R7 (Selenomonas sp. MCB2), R8 (Selenomonas ruminantium gene) and R9 (Selenomonas ruminantium strain LongY6) were found in samples with higher proportions of SS. Different feed ratios affect rumen fermentation in terms of $\mathrm{pH}, \mathrm{NH}_{3}-\mathrm{N}, \mathrm{CH}_{4}, \mathrm{BA}$, volatile fatty acid and other metabolite concentrations and microbial diversity. Balanced protein and carbohydrate ratios are needed for rumen fermentation. (Key Words: 16S rDNA Denaturing Gradient Gel Electrophoresis, Biogenic Amine, In vitro Rumen Fermentation, Soybean Meal and Soluble Starch Ratio)
\end{abstract}

\section{INTRODUCTION}

Among the several feed ingredients used as animal feed

\footnotetext{
* Corresponding Author: Sang-Suk Lee. Tel: +82-61-750-3237, Fax: +82-61-750-3237, E-mail: rumen@ sunchon.ac.kr

1 Department of Animal Resource Technology, Gyeongnam National University of Science and Technology, Jinju 660-758, Korea.

${ }^{2}$ Department of Life Science, Chung-Ang University, Seoul 156756, Korea.

${ }^{3}$ Division of Applied Science, Graduate School of Gyeongsang National University, IALS, Jinju 660-701, Korea.

Submitted Jul. 23, 2014; Revised Sept. 10, 2014; Accepted Sept. 29, 2014
}

over the years, two most commonly used are soybean meal (SM) and starch. Soybean meal has been a part of staple diet of high-producing dairy and beef cattle in developed countries. It is well degraded in the rumen and produces ammonia, amino acids, and peptides for ruminal microbial protein synthesis. Positive effects on feed intake, milk yield and milk protein content were observed in dairy cows when supplemented with SM (MacDonald et al., 1998). On the other hand, starch has been used as a source of carbohydrates and as a binder in calf milk replacers. It is a potentially entirely digestible in the rumen, but its solubility and its digestion rate can vary largely according to the source of starch and the technological process (Offner et al., 
2003). However, it is also rapidly digested and does not promote chewing and saliva recycling and thus can induce ruminal acidosis. Consequently, its inclusion must be limited in ruminant diets.

Rumen bacteria require sources of nitrogen, minerals, vitamins, and growth factors for their growth; however, nitrogen and energy are required in the largest quantities and must be simultaneously available to stimulate rapid growth of bacteria. Both dietary and ruminal microbes are the sources of amines in ruminants. Thus, greater amounts of amines are available for absorption in ruminants than other species. Nevertheless, increased contents of dietary amines tend to reduce dry matter intake (Van Os et al., 1995), nitrogen degradability in the rumen of steers, particularly by the biogenic amine (BA) putrescine (Dawson and Mayne, 1997), have negative effects on visceral organs and meat quality (Fusi et al., 2004) of ruminants, hence it has been considered disadvantageous. Functional studies regarding the relationship between BA histamine concentration and hyperacidity during metabolic studies has been reported in non ruminants as well as in ruminants. In ruminants, the absorption of histamine leading to systemic acidosis is due to luminal acidityinduced ruminal epithelial damage and not histamine as reported Aschenbach and Gabel (2000). On the other hand, a close relationship between ruminal and histamine profiles in preacidotic stages induced by high concentrate diet fed to cattle was reported (Motoi et al., 1984), but the effects of various ratios and synchronization of protein and carbohydrates on rumen fermentation and their effects on rumen microbial diversity and BA production were not thoroughly investigated. Hence, this study was conducted to determine the effects of SM and soluble starch (SS) on BA and microbial diversity using in vitro ruminal fermentation.

\section{MATERIALS AND METHODS}

Two gram samples with different ratios of SM to SS were investigated through in vitro analysis. The treatments involved $2 \mathrm{~g}$ mixtures of varying ratios of SM:SS as follows: Control (no substrate added), 10:0, 7:3, 5:5, 3:7, and 0:10 (expressed on 10 parts basis). Rumen fluid was collected from cannulated Holstein Friesian cattle, immediately strained through four layers of surgical gauze and placed in amber bottles with an oxygen free headspace. The collected rumen fluid was then sealed and immediately transported to the laboratory. Upon arrival in the laboratory, Russell and Van Soest (1984) buffer solution and rumen fluid were mixed at a 4:1 ratio and adjusted to $\mathrm{pH} 6.7$. Next, $100 \mathrm{~mL}$ of prepared medium was dispensed into $160 \mathrm{~mL}$ serum bottles anaerobically under $\mathrm{O}_{2}$-free $\mathrm{CO}_{2}$ and incubated at $39^{\circ} \mathrm{C}$ and $90 \mathrm{rpm}$ for $0,12,24$, or $48 \mathrm{~h}$. Total gas, $\mathrm{pH}$, ammonia nitrogen $\left(\mathrm{NH}_{3}-\mathrm{N}\right), \mathrm{CH}_{4}, \mathrm{BA}$, volatile fatty acid
(VFA) and other metabolites were analyzed after incubation.

\section{Analyses for in vitro fermentation parameters}

Total gas production at different stages was measured in each serum bottle using a sensor machine (Laurel Electronics, Inc., Costa Mesa, CA, USA), while pH was measured with a Pinnacle series M530p meter (Schott Instruments, Mainz, Germany) after uncapping each of the bottles. The $\mathrm{NH}_{3}-\mathrm{N}$ concentration (Chaney and Marbach (1962), VFA and other metabolites (high performance liquid chromatography (HPLC), Agilent Technologies 1200 series, Tokyo, Japan) (Tabaru et al. (1988) and Han et al. (2005) and expected $\mathrm{CH}_{4}$ production was calculated from the relationship between $\mathrm{CH}_{4}$ and short chain fatty acids (Demeyer and Van Nevel, 1975). Moreover, the expected $\mathrm{CH}_{4}$ production was determined from the relationship between $\mathrm{CH}_{4}$ and VFA (Gagen et al., 2012) using the following calculation:

\section{$\mathrm{M}=0.45$ Acetate -0.25 Propionate +0.40 Butyrate}

The BA concentrations were analyzed by high performance liquid chromatography (HPLC). Amine separation was conducted using HPLC (Waters Ltd., Milford, MA, USA) and a Varian column (Pursuit $\times$ Rs 5u C$18250 \times 4.6 \mathrm{~mm}$ ) (Varian Inc., Lake Forest, CA, USA) with a fluorescence detector (Waters 470, Waters Corporation, Milford, MA, USA) set to an excitation wavelength of 330 $\mathrm{nm}$ and an emission wavelength of $418 \mathrm{~nm}$. Amine compounds were identified and quantified based on comparison with standard curves constructed from pure compounds (histamine, methylamine, ethylamine and tyramine). The assay sensitivity for each amine was calculated by extrapolation from a dilution curve and was taken as the lowest concentration required to produce a signal-to-noise ratio of 3:1 (Snyder et al., 1997). The chromatographic data used was generated by a Mellenium32 System (Waters Millipore, Milford, MA, USA) program. HPLC samples were centrifuged at $16,609 \times \mathrm{g}$ for $5 \mathrm{~min}$ at $4^{\circ} \mathrm{C}$ and then filtered through $0.2 \mu \mathrm{m}$ millipore filters. Next, samples and $6 \mathrm{~N} \mathrm{HCl}$ were vortexed and hydrolyzed in an oven at $110^{\circ} \mathrm{C}$ for $24 \mathrm{~h}$, after which an Eyela SB-1000 evaporator (Tokyo Rikakikai Co. Ltd., Tokyo, Japan) was used to remove the $\mathrm{HCl}$. The majority of the solutions used for HPLC were obtained from SigmaAldrich (Seelze, Germany). Prior to sample analysis, a standard with an $r^{2}$ between 0.98 and 1.0 was developed.

Fermented samples (preserved) were extracted using Wizard Genomic DNA Purification Kits (Promega, Madison, WI, USA), after which 16S rDNA PCR amplification was performed using the 27F and 1492R universal primers. Denaturing gradient gel electrophoresis 
(DGGE) was conducted using a D-Code Universal Mutation Detection System (BioRad, Hercules, CA, USA). To amplify the V3 region of the bacterial 16S rDNA amplicons, 341F-GC and 518R were used (Nubel et al., 1996). Amplicons of the V3 region of 16S rDNA were used for sequence-specific separation by DGGE as described by Muyzer and Smalla (1998). The DGGE gel was scanned at $400 \mathrm{dpi}$ and similarity indices were calculated for pairs of DGGE profiles. The number of DGGE bands and similarity indices were calculated from the densitometric curves of the scanned DGGE profiles using the Molecular Analyst 1.12 software (BioRad, USA) with the Pearson product-moment correlation coefficient (Hane et al., 1993) from the Central Microbiology Laboratory of SCNU in Korea.

A total of eight purified dominant bands were sent to Macrogen, Seoul, Korea for sequencing, and the results were compared to sequences available in the GenBank database using the BLAST tool of the National Center for Biotechnology Information and EzTaxon.

\section{Statistical analysis}

Data were analyzed by analysis of variance using the general linear model for a randomized complete block design. All treatments were conducted in triplicate and Duncan's Multiple Range Test was used to identify differences between specific treatments. A $p<0.05$ was considered to indicate statistical significance. All analyses were carried out using Statistical Analysis Systems (SAS) version 9.1 (2002).

\section{RESULTS}

Total gas production of samples containing different SM to SS ratios during in vitro fermentation for various incubation times are shown in Table 1. Total gas production increased as incubation time increased. Production in control $(21.33 \mathrm{~mL})$ was lowest $(\mathrm{p}<0.05)$ among treatment groups, while treatments with higher levels of SM had higher $(\mathrm{p}<0.05)$ gas production than those with higher proportions of SS. As expected, $\mathrm{pH}$ decreased as incubation increased (Table 1). Moreover, the treatments with higher proportions of SS had lower $\mathrm{pH}$ values than those with higher proportions of SM after 24 and $48 \mathrm{~h}$ of incubation. In addition, the $\mathrm{NH}_{3}-\mathrm{N}$ concentration changed from 0 to $48 \mathrm{~h}$, with the greatest levels $(\mathrm{p}<0.05)$ occurring in exclusively SM containing mixture $(28.75 \mathrm{mM})$ (Table 1). Exclusively SS had the lowest $(\mathrm{p}<0.05) \mathrm{NH}_{3}-\mathrm{N}$ concentration in all of the groups after $24 \mathrm{~h}$ of incubation. As shown in Table 1, increasing $\mathrm{CH}_{4}$ concentrations were observed from 0 to 48 $\mathrm{h}$ of incubation. At $12 \mathrm{~h}$ of incubation, the highest $(\mathrm{p}<0.05)$ $\mathrm{CH}_{4}$ concentration was observed on exclusively SM. After $24 \mathrm{~h}$ incubation, exclusively $\mathrm{SM}$ and 5:5 ratio had the highest $(\mathrm{p}<0.05) \mathrm{CH}_{4}$ concentrations at with 70.72 and $67.17 \mathrm{mM}$, respectively and then after $48 \mathrm{~h}$ of incubation,

Table 1. Total gas, $\mathrm{pH}$, ammonia-nitrogen $\left(\mathrm{NH}_{3}-\mathrm{N}\right)$ and methane $\left(\mathrm{CH}_{4}\right)$ production during in vitro rumen fermentation using different ratios of soybean meal and soluble starch

\begin{tabular}{|c|c|c|c|c|c|c|c|}
\hline \multirow{2}{*}{ Incubation time $(\mathrm{h})$} & \multicolumn{6}{|c|}{ Soybean meal: soluble starch ratio } & \multirow{2}{*}{ SEM } \\
\hline & Control & 10:0 & $7: 3$ & $5: 5$ & $3: 7$ & $0: 10$ & \\
\hline & \multicolumn{7}{|c|}{------------------------------------------- Gas production (mL) ------------------------------------- } \\
\hline 0 & 0.00 & 0.00 & 0.00 & 0.00 & 0.00 & 0.00 & 0.000 \\
\hline 12 & $8.00^{\mathrm{e}}$ & $66.00^{\mathrm{b}}$ & $71.66^{\mathrm{a}}$ & $63.67^{\mathrm{b}}$ & $54.33^{\mathrm{c}}$ & $45.00^{\mathrm{d}}$ & 1.271 \\
\hline 24 & $15.67^{\mathrm{e}}$ & $89.33^{\mathrm{b}}$ & $93.67^{\mathrm{a}}$ & $86.33^{\mathrm{a}}$ & $82.67^{\mathrm{c}}$ & $67.67^{\mathrm{d}}$ & 0.959 \\
\hline 48 & $21.33^{\mathrm{c}}$ & $107.67^{\mathrm{a}}$ & $111.00^{\mathrm{a}}$ & $109.33^{\mathrm{a}}$ & $109.33^{\mathrm{a}}$ & $80.33^{\mathrm{b}}$ & 2.294 \\
\hline 0 & $6.46^{\mathrm{a}}$ & $6.37^{\mathrm{b}}$ & $6.40^{\mathrm{ab}}$ & $6.40^{\mathrm{ab}}$ & $6.40^{\mathrm{ab}}$ & $6.40^{\mathrm{ab}}$ & 0.020 \\
\hline 12 & $6.38^{\mathrm{a}}$ & $5.79^{\mathrm{b}}$ & $5.47^{\mathrm{c}}$ & $5.43^{c}$ & $5.51^{\mathrm{c}}$ & $5.55^{\mathrm{c}}$ & 0.041 \\
\hline 24 & $6.42^{\mathrm{a}}$ & $5.65^{\mathrm{b}}$ & $5.16^{\mathrm{c}}$ & $5.14^{\mathrm{c}}$ & $5.13^{\mathrm{c}}$ & $4.98^{\mathrm{d}}$ & 0.028 \\
\hline 48 & $6.37^{\mathrm{a}}$ & $5.68^{\mathrm{b}}$ & $5.09^{c}$ & $4.81^{\mathrm{d}}$ & $4.79^{\mathrm{d}}$ & $4.74^{\mathrm{d}}$ & 0.020 \\
\hline & & & $\mathrm{NH}_{3}-\mathrm{N}$ & ration $(\mathrm{n}$ & -10 & & \\
\hline 0 & $4.93^{\mathrm{b}}$ & $7.62^{\mathrm{a}}$ & $7.16^{\mathrm{ab}}$ & $6.96^{\mathrm{ab}}$ & $5.18^{\mathrm{ab}}$ & $7.62^{\mathrm{a}}$ & 0.544 \\
\hline 12 & $8.54^{\mathrm{c}}$ & $15.10^{\mathrm{a}}$ & $10.62^{\mathrm{b}}$ & $9.30^{\mathrm{bc}}$ & $8.57^{\mathrm{c}}$ & $6.65^{\mathrm{d}}$ & 0.475 \\
\hline 24 & $9.68^{\mathrm{cd}}$ & $20.89^{\mathrm{a}}$ & $14.07^{\mathrm{b}}$ & $12.49^{\mathrm{bc}}$ & $8.30^{\mathrm{de}}$ & $5.25^{\mathrm{e}}$ & 0.375 \\
\hline 48 & $16.99^{\mathrm{b}}$ & $28.75^{\mathrm{a}}$ & $15.94^{\mathrm{b}}$ & $9.62^{\mathrm{c}}$ & $8.11^{\mathrm{c}}$ & $5.80^{\mathrm{d}}$ & 0.414 \\
\hline & & & ---- Met & nM) ----- & -1 & - & \\
\hline 0 & 30.97 & 34.64 & 32.45 & 32.07 & 31.74 & 30.57 & 0.476 \\
\hline 12 & $28.05^{\mathrm{d}}$ & $55.69^{\mathrm{a}}$ & $42.15^{\mathrm{b}}$ & $39.93^{c}$ & $38.78^{\mathrm{c}}$ & $34.10^{\mathrm{c}}$ & 1.133 \\
\hline 24 & $28.24^{\mathrm{e}}$ & $70.72^{\mathrm{a}}$ & $62.52^{\mathrm{bc}}$ & $67.17^{\mathrm{ab}}$ & $58.16^{\mathrm{c}}$ & $51.80^{\mathrm{d}}$ & 2.230 \\
\hline 48 & $44.05^{\mathrm{c}}$ & $80.12^{\mathrm{a}}$ & $81.27^{\mathrm{a}}$ & $80.18^{\mathrm{a}}$ & $75.39^{\mathrm{a}}$ & $59.82^{\mathrm{b}}$ & 1.159 \\
\hline
\end{tabular}

SEM, standard error of the mean.

Means with different superscripts in a row differ significantly $(\mathrm{p}<0.05)$. 
Table 2. Biogenic amine concentration $(\mathrm{mM})$ at $48 \mathrm{~h}$ during in vitro rumen fermentation using different ratios of soybean meal and soluble starch

\begin{tabular}{lcccccc}
\hline \multirow{2}{*}{ Amines } & \multicolumn{3}{c}{ Soybean meal:soluble starch ratio } \\
\cline { 2 - 7 } & Control & $10: 0$ & $7: 3$ & $5: 5$ & $3: 7$ & $0: 10$ \\
\hline Histamine & $0.013^{\mathrm{c}}$ & $3.230^{\mathrm{a}}$ & $2.134^{\mathrm{b}}$ & $0.020^{\mathrm{c}}$ & $0.026^{\mathrm{c}}$ & $0.015^{\mathrm{c}}$ \\
Methylamine & $\mathrm{ND}$ & 0.198 & 0.017 & $\mathrm{ND}$ & $\mathrm{ND}$ & $\mathrm{ND}$ \\
Ethylamine & $\mathrm{ND}$ & 0.376 & 0.072 & $\mathrm{ND}$ & $\mathrm{ND}$ & $\mathrm{ND}$ \\
Tyramine & $\mathrm{ND}$ & $\mathrm{ND}$ & $\mathrm{ND}$ & $\mathrm{ND}$ & $\mathrm{ND}$ & $\mathrm{ND}$ \\
Phenylethylamine & $\mathrm{ND}$ & $\mathrm{ND}$ & $\mathrm{ND}$ & $\mathrm{ND}$ & $\mathrm{ND}$ & $\mathrm{ND}$ \\
Putrescine & $\mathrm{ND}$ & 0.863 & 0.222 & 0.000 & 0.000 & $\mathrm{ND}$ \\
Cadaverine & $\mathrm{ND}$ & 0.343 & 0.071 & $\mathrm{ND}$ & $\mathrm{ND}$ & ND \\
Amine index & $0.013^{\mathrm{b}}$ & $4.436 \mathrm{a}$ & $2.427^{\mathrm{a}}$ & $0.020^{\mathrm{b}}$ & $0.026 \mathrm{~b}$ & $0.015^{\mathrm{b}}$ \\
Total amine & $0.013^{\mathrm{c}}$ & $5.009^{\mathrm{a}}$ & $2.516^{\mathrm{b}}$ & $0.020^{\mathrm{c}}$ & $0.026^{\mathrm{c}}$ & $0.015^{\mathrm{c}}$ \\
\hline
\end{tabular}

ND, not detected.

Means with different superscripts in a row differ significantly $(\mathrm{p}<0.05)$.

the highest $(\mathrm{p}<0.05)$ levels were observed in exclusively SM, 7:3, 5:5, and 3:7 ratio with $80.12,81.27,80.18$, and $75.93 \mathrm{mM}$, respectively.

The BA concentration of rumen microbial in vitro fermentation is shown in Table 2. Most of the BA was higher or only detected with higher proportions of SM. The histamine concentration was highest $(\mathrm{p}<0.05)$ in exclusively SM with $3.230 \mathrm{mM}$ followed by $7: 3,3: 7,5: 5$, exclusively SS and control, respectively after $48 \mathrm{~h}$ of incubation. Methylamine, putrescine and cadaverine were only detected in exclusively $\mathrm{SM}$ and 7:3 ratios. In addition, highest $(\mathrm{p}<0.05)$ amine index and total amine were observed in exclusively SM and 7:3. Table 3 shows the VFA and other metabolite concentrations during in vitro rumen fermentation at different incubation times. A higher proportion of SS was associated with significantly higher total volatile fatty acids (TVFA), propionate and butyrate production than higher proportions of SM (Table 3). After $24 \mathrm{~h}$ of incubation, highest $(\mathrm{P}<0.05)$ propionate concentration was observed in 5:5, 3:7 and exclusively SS proportions with $20.45,20.77$, and $21.48 \mathrm{mM}$, respectively and after $48 \mathrm{~h}$ of incubation it was highest $(\mathrm{p}<0.05)$ in

Table 3. Volatile fatty acids (VFA) concentrations (mM) during in vitro rumen fermentation using different ratios of soybean meal and soluble starch

\begin{tabular}{|c|c|c|c|c|c|c|c|c|}
\hline \multirow{2}{*}{ VFA } & \multirow{2}{*}{$\begin{array}{c}\text { Incubation } \\
\text { time (h) }\end{array}$} & \multicolumn{6}{|c|}{ Soybean meal:soluble starch ratio } & \multirow{2}{*}{ SEM } \\
\hline & & Control & $10: 0$ & $7: 3$ & $5: 5$ & $3: 7$ & $0: 10$ & \\
\hline \multirow[t]{4}{*}{ Acetate } & 0 & $18.38^{\mathrm{cd}}$ & $20.56^{\mathrm{a}}$ & $19.26^{\mathrm{b}}$ & $19.03^{\mathrm{bc}}$ & $18.84^{\mathrm{bc}}$ & $18.15^{\mathrm{d}}$ & 0.302 \\
\hline & 12 & $20.09^{c}$ & $32.16^{\mathrm{b}}$ & $35.31^{\mathrm{a}}$ & $35.00^{\mathrm{a}}$ & $34.47^{\mathrm{a}}$ & $30.59^{\mathrm{b}}$ & 0.509 \\
\hline & 24 & $20.21^{\mathrm{c}}$ & $41.52^{\mathrm{a}}$ & $39.53^{\mathrm{ab}}$ & $41.21^{\mathrm{a}}$ & $38.41^{\mathrm{ab}}$ & $36.85^{\mathrm{b}}$ & 0.614 \\
\hline & 48 & $19.66^{\mathrm{d}}$ & $47.04^{\mathrm{a}}$ & $43.87^{\mathrm{ab}}$ & $40.18^{\mathrm{bc}}$ & $36.80^{\mathrm{c}}$ & $36.22^{\mathrm{c}}$ & 0.603 \\
\hline \multirow[t]{4}{*}{ Propionate } & 0 & ND & ND & ND & ND & ND & ND & \\
\hline & 12 & $5.01^{\mathrm{c}}$ & $9.69^{\mathrm{b}}$ & $15.01^{\mathrm{a}}$ & $16.48^{\mathrm{a}}$ & $16.71^{\mathrm{a}}$ & $15.09^{\mathrm{a}}$ & 0.536 \\
\hline & 24 & $5.02^{\mathrm{d}}$ & $14.10^{\mathrm{c}}$ & $17.17^{\mathrm{b}}$ & $20.45^{\mathrm{a}}$ & $20.77^{\mathrm{a}}$ & $21.48^{\mathrm{a}}$ & 0.540 \\
\hline & 48 & $5.50^{\mathrm{d}}$ & $17.10^{\mathrm{c}}$ & $19.00^{c}$ & $20.82^{\mathrm{b}}$ & $20.97^{b}$ & $24.96^{\mathrm{a}}$ & 0.790 \\
\hline \multirow[t]{4}{*}{ Butyrate } & 0 & ND & ND & ND & ND & ND & ND & \\
\hline & 12 & ND & 5.78 & ND & ND & ND & ND & 0.097 \\
\hline & 24 & ND & $7.76^{\mathrm{b}}$ & $7.16^{\mathrm{b}}$ & $9.72^{\mathrm{a}}$ & $7.93^{\mathrm{b}}$ & 6.61 & 0.328 \\
\hline & 48 & $7.86^{\mathrm{c}}$ & $9.38^{\mathrm{bc}}$ & $13.33^{\mathrm{ab}}$ & $16.62^{\mathrm{a}}$ & $17.11^{\mathrm{a}}$ & $12.57^{\mathrm{abc}}$ & 1.054 \\
\hline \multirow[t]{4}{*}{ Total VFA } & 0 & 18.38 & 20.56 & 19.26 & 19.03 & 18.84 & 18.15 & 0.302 \\
\hline & 12 & $25.10^{\mathrm{c}}$ & $47.62^{\mathrm{ab}}$ & $50.32^{\mathrm{a}}$ & $51.48^{\mathrm{ab}}$ & $51.17^{\mathrm{ab}}$ & $45.67^{\mathrm{b}}$ & 1.142 \\
\hline & 24 & $25.23^{\mathrm{d}}$ & $63.39^{\mathrm{bc}}$ & $63.86^{\mathrm{bc}}$ & $71.37^{\mathrm{a}}$ & $67.12^{\mathrm{ab}}$ & $64.95^{\mathrm{c}}$ & 1.482 \\
\hline & 48 & $33.03^{c}$ & $73.52^{\mathrm{b}}$ & $76.20^{\mathrm{ab}}$ & $77.62^{\mathrm{a}}$ & $74.88^{\mathrm{ab}}$ & $73.76^{\mathrm{ab}}$ & 2.447 \\
\hline \multirow[t]{4}{*}{$\mathrm{A} / \mathrm{P}$} & 0 & ND & ND & ND & ND & ND & ND & \\
\hline & 12 & $4.01^{\mathrm{a}}$ & $3.32^{\mathrm{b}}$ & $2.35^{\mathrm{c}}$ & $2.12^{\mathrm{d}}$ & $2.06^{\mathrm{d}}$ & $2.03^{\mathrm{d}}$ & 0.95 \\
\hline & 24 & $4.02^{\mathrm{a}}$ & $2.94^{\mathrm{b}}$ & $2.30^{\mathrm{c}}$ & $2.02^{\mathrm{d}}$ & $1.85^{\mathrm{de}}$ & $1.72^{\mathrm{e}}$ & 1.14 \\
\hline & 48 & $3.57^{\mathrm{a}}$ & $2.75^{\mathrm{b}}$ & $2.31^{\mathrm{c}}$ & $1.93^{\mathrm{d}}$ & $1.76^{\mathrm{e}}$ & $1.45^{\mathrm{f}}$ & 0.76 \\
\hline
\end{tabular}

SEM, standard error of the mean; ND, not detected; A/P, acetate propionate ratio.

Means with different superscripts in a row differ significantly $(\mathrm{p}<0.05)$. 


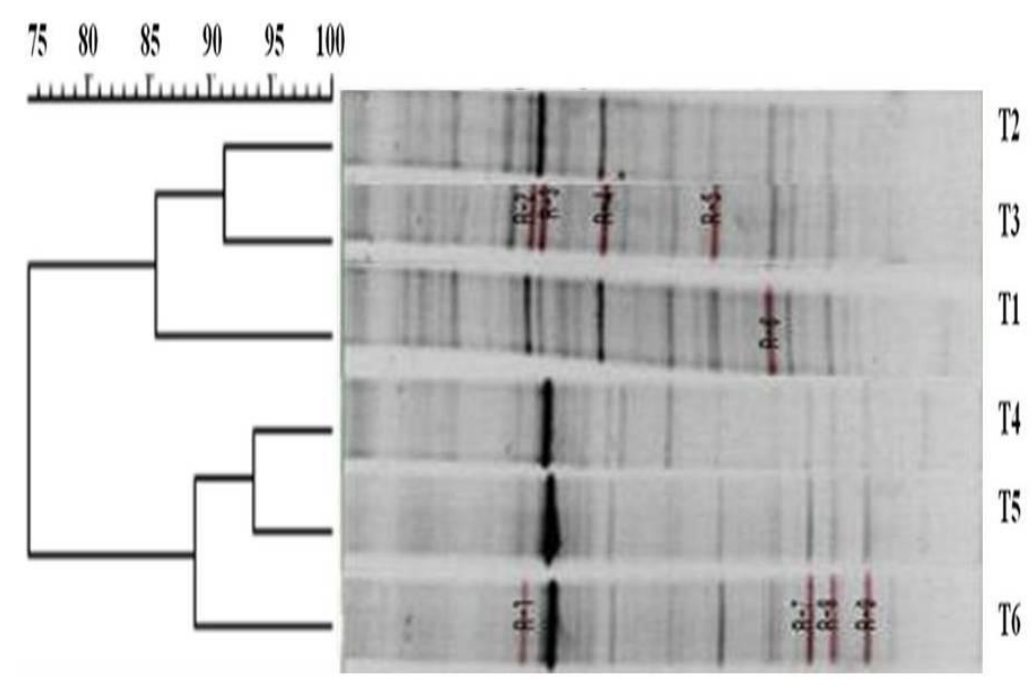

Figure 1. Negative image and similarity index of $16 \mathrm{~S}$ rDNA amplified DGGE band profiles using total genomic DNA extracted after 48 $\mathrm{h}$ of in vitro rumen fermentation using different ratios of soybean meal and soluble starch. DGGE, denaturing gradient gel electrophoresis; SM, soybean meal; $\mathrm{T} 1=$ Control; $\mathrm{T} 3=\mathrm{SM}$ 7: SS 3; T5 = SM 3: SS 7; SS, soluble starch; T2 = SM 10: SS 0; T4 = SM 5: SS 5; T6 = SM 0: SS 10 .

exclusively SS with $24.96 \mathrm{mM}$. Conversely, the highest $(\mathrm{p}<0.05)$ concentration of acetate was observed in samples with the highest proportion of SM, exclusively SM and 7:3, after $48 \mathrm{~h}$ of incubation with 47.04 and $43.87 \mathrm{mM}$, respectively.

The similarity index and negative image of $16 \mathrm{~S}$ rDNA amplified DGGE band profiles was obtained using total genomic DNA extracted from in vitro fermentation after 48 $\mathrm{h}$ of incubation (Figure 1). The Unweighted Pair Group Method with Arithmetic mean (UPGMA) showed that treatment groups were divided into control, exclusively SM, $7: 3$ and 5:5, 3:7, exclusively SS with $75 \%$ similarity. In group 1, exclusively SM, and 7:3 ratio were $91 \%$ similar to each other and $85 \%$ similar to the control. In group 2, 5:5, and 3:7 ratios were $94 \%$ similar to each other and $89 \%$ similar to exclusively SS. Nine dominant bands were selected, cut, sequenced and identified (Table 4). The sequences were found to be $87 \%$ to $100 \%$ homologous with those available in the GenBank database, most of which were from bacteria isolated from the rumen. R2 and R4 bands were found on higher proportion of SM while R3, R7, $\mathrm{R} 8$, and $\mathrm{R} 9$ bands were found in higher proportion of SS.

\section{DISCUSSION}

Rumen fermentation since the beginning of the century

Table 4. Dominant bands from 16S rDNA amplified DGGE of in vitro rumen fermentation using different ratios of soybean meal and soluble starch

\begin{tabular}{llcc}
\hline Sample & Strains (Accession no.) & Identity & Isolation \\
\hline R-1 & Uncultured bacterium clone BB2_h06 (EU458259) & $96 / 110$ & North American black bear feces \\
& & $(87 \%)$ & Rumen \\
R-2 & Uncultured bacterium clone RB-5E1 (FJ172825) & $130 / 139$ & $(93 \%)$ \\
& & $127 / 127$ & Fecal sample \\
R-3 & Uncultured Firmicutes bacterium clone NI_52 (FJ650961) & $(100 \%)$ & Rumen liquid phase of \\
& & $126 / 128$ & fistulated Holstein Heifer \\
R-4 & Uncultured rumen bacterium clone L7A_C10 (EU381645) & $(98 \%)$ & ND \\
& & & Rumen \\
R-5 & ND & $134 / 147$ & $(91 \%)$ \\
R-6 & Uncultured rumen bacterium clone CF376 (EU871409) & $147 / 149$ & Yak rumen in the Tibetan plateau \\
& & $(98 \%)$ & Sheep rumen \\
R-7 & Selenomonas sp. MCB2 (EF195237) & $148 / 153$ & Rumen \\
& & $(96 \%)$ & $(97 \%)$ \\
R-8 & Selenomonas ruminantium gene(AB198437) & $146 / 150$ & \\
& &
\end{tabular}


revealed that availability of rumen-degradable proteins (non-protein nitrogen and rumen degradable true protein) and energy (ruminally fermentable carbohydrate) in feeds as well as their synchronization are important in ruminants' diet. The provision of both rumen-degradable proteins and energy simultaneously to the rumen is called synchronization (Seo et al., 2010). The determination of rumen microbial species, their environmental and nutritional requirements, and the characteristics of feeds have been thoroughly investigated, with energy and nitrogen sources being the primary focus of attention. However, rumen fermentation is affected by $\mathrm{pH}$ and turnover rate, which are determined by intake levels, feeding systems, particle size and quality of forage, and proportion and type of carbohydrate ingested. Some of these attributes have been investigated in this study.

As SM is known to have high degradability which is further subjected to rumen microbial fermentation during metabolism and conversion of the substrates, higher gas production of samples containing higher proportions of soybean can be expected. It could also be due to high contents of easily fermentable starches, sugars, or hemicelluloses as substrate to rumen microbes for gas production. Getachew et al. (2004) reported that the digestibility of the measured organic matter was closely related to that predicted from gas production and the crude protein and ash contents of feeds. They also found a high correlation between metabolizable energy measured in live animals and that predicted from gas production. On the other hand, the $\mathrm{pH}$ decreased as the incubation time increased, which was comparable to the results obtained by Russell and Baldwin (1979), who reported that these changes were due to the production of lactic acid. Martin and Streeter (1995) also observed that the $\mathrm{pH}$ was lower in SS than SM, and that the concentrations of most fermentation products were much higher than those observed in the absence of carbohydrates, and our results corroborate with these finding. Starch hydrolysis or fermentation by microorganisms caused increases amounts of lactic acid and alcohol, which are responsible for decreased $\mathrm{pH}$ in the rumen (Walker and Harmon, 1995). As a result, low fiber digestion occurs when the $\mathrm{pH}$ value decreases below 6.2 due to decreased levels of fiber degrading bacteria. Also, decreased in $\mathrm{pH}$ can lead to subacute ruminal acidosis (SARA) (Plaizier et al., 2008). Reduced ruminal efficiency, liver and lung abscesses, and laminitis are all thought to be related to SARA (Stone, 2004).

Higher $\mathrm{CH}_{4}$ concentrations were found in SM than SS. This might have been due to the nutrient composition of feed, grain type and processing, and microbial digestibility. High $\mathrm{CH}_{4}$ production might also be attributed to the high contents of easily fermentable starches, sugars, or hemicelluloses as substrate to rumen microbes for gas production. Van Kessel and Russell (1996) stated that highly digestible carbohydrate undergoes rapid decomposition inside the rumen and causes a reduction in ruminal $\mathrm{pH}$, which inhibits the activity of $\mathrm{CH}_{4}$ producing microorganisms and protozoa. Thus, low $\mathrm{CH}_{4}$ production was observed in response to a high proportion of SS.

The $\mathrm{NH}_{3}-\mathrm{N}$ level depends on the presence of microbial protein in the rumen (Mamuad et al., 2014), which also depends on the level of the carbohydrate level. Specifically, if the carbohydrate level increases, then both $\mathrm{NH}_{3}$ and microbial protein will decrease, although microbial protein synthesis efficiency depends on the quantity of carbohydrate fermentation. According to Kim et al. (2012), the levels of $\mathrm{NH}_{3}-\mathrm{N}$ in the rumen are generally high when feeds are more digestible. The mixture with only SM which had high protein content as substrate produced high concentration of $\mathrm{NH}_{3}-\mathrm{N}$. However, Fenderson and Bergen (1976) reported that when steers were fed with high protein rations, it resulted to high ruminal ammonia levels and elevated plasma urea nitrogen concentrations. This might lead to ammonia toxicity.

Amines are produced by decarboxylation of amino acids via enzymes produced by putrefactive bacteria as well as many species and strains of lactic acid bacteria. Microbial species associated with fermented food and beverages releases exogenous decarboxylases which forms BA. They are biologically active compounds with aliphatic (putrescine, spermidine, spermine), aromatic (dopamine, tyramine, phenylethylamine), or heterocyclic (histamine, serotonin) structures. Several BA play critical roles in human and animal physiological functions such as regulation of body temperature, stomach volume and $\mathrm{pH}$, and brain activity. Ruminants potentially receive amines from both dietary and ruminal microbial sources and thus have potentially greater amount available for absorption than other species (Phuntsok et al., 1998). Steidlova and Kalac (2002) mentioned that high levels of BAs are common in silages prepared from forages with high protein content (e.g., alfalfa, clover, some grasses). They also reported that high levels of BAs were observed in maize silages. BAs are also present in all natural products in which protein degradation has occurred. Thus, treatments with high proportion of SM (highly degradable protein) were observed to be also high in BAs. In addition, increased contents of dietary amines have been found to be undesirable in ruminant nutrition.

Methylamine, which is also a BA, is used as a substrate for methanogenesis (Thauer, 1998). This explains the high $\mathrm{CH}_{4}$ concentration observed in high proportion of SM which was also detected with high concentration of methylamine. In addition, high proportion of SM (high protein content) also leads to production of high concentration of histamine. Aschenbach and Gabel (2000) 
added that absorption of ruminal histamine is an important cause of systemic histaminosis in ruminants suffering from ruminal acidosis. They also added that histamine absorption is linked to luminal epithelial damage, which is primarily induced by luminal acidity and not by histamine. However, histamine is thought to worsen blood circulation in limbs. Furthermore, high histamine concentration might lead to SARA and might cause bovine laminitis (Krizek et al., 1993).

Polyamines such as putrescine are important in the synthesis of proteins, RNA, and DNA, and are therefore essential for cell proliferation and growth (Aschenbach and Gabel, 2000). However, putrescine is the causative factor in ketonemia and high concentration of putrescine leads to ketonemia (Tveit et al., 1992). Consequently, putrescine infusion treatment significantly reduced nitrogen degradability in the rumen of steer (Dawson and Mayne, 1996). On the other hand, tyramine infusion has been shown to increase $\mathrm{pH}$ and isovalerate proportion in rumen fluid Tveit et al. (1992). Our observations that higher $\mathrm{pH}$ was associated with (the detection of) tyramine in feed containing higher proportions of SM correspond with those of Tveit et al. (1992).

van Beers-Schreurs et al. (1998) stated that the quantity of VFA depends on the amount and composition of the substrate and thus SM and SS were converted into different concentrations of VFA. Mamuad et al. (1998) added that lower VFA concentrations reflect lower amounts of fermented substrate, lower quantities of microbial activity and lower energy intake. Soybean meal fermentation is lower than SS. Hence, lower VFA concentrations were observed in SM substrate than SS. Our results agrees with those of Van Nevel and Demeyer (2014), who found that feeding diets rich in soluble carbohydrates and starch to ruminants resulted in increased propionate and $\mathrm{CH}_{4}$ production and a decreased acetate: propionate ratio.

Groupings of different treatments based on similarity index showed that changes in ruminal fermentation were affected by the substrate used for fermentation. Mao et al. (1977) reported rumen microbial community changes in response to variations in the type and level of the feed. Williams (2008) reported enhanced growth of Selenomonas ruminantium and Streptococcus bovis in response to high SS levels, which is in accordance with the high level of SS, which were identified as Selenomonas sp. Martin and Streeter (1986) added that $S$. ruminantium, the predominant ruminal bacterium, uses the succinate-propionate pathway, which is essential for energy production. Important microorganisms such as Selenomonas disappeared in the presence of higher proportions of SM, while cellulolytic bacteria might disappear with higher proportion of SS. Also, higher proportion of SS will lead to acidosis and then SARA and then laminitis.
Different feed ratios affect rumen fermentation in terms of $\mathrm{pH}, \mathrm{NH}_{3}-\mathrm{N}, \mathrm{CH}_{4}, \mathrm{BA}, \mathrm{VFA}$, and other metabolite concentrations, and microbial diversity. A higher proportion of SM increased BA, while a higher proportion of SS drastically decreased $\mathrm{pH}$ over time which might lead to subacute ruminal acidosis. Both parameters had a negative impact on rumen fermentation. Overall, these findings indicate that a balanced SM and SS ratio is needed for rumen fermentation.

\section{ACKNOWLEDGMENTS}

This work was carried out with support of "Cooperative Research Program for Agriculture Science and Technology Development (Project No. PJ0091562014 and PJ0105212015)", Rural Development Administration, Republic of Korea.

\section{REFERENCES}

Aschenbach, J. R. and G. Gabel. 2000. Effect and absorption of histamine in sheep rumen: Significance of acidotic epithelial damage. J. Anim. Sci. 78:464-470.

Chaney, A. L. and E. P. Marbach. 1962. Modified reagents for determination of urea and ammonia. Clin. Chem. 8:130-132.

Dawson, L. E. R. and C. S. Mayne. 1996. The effect of intraruminal infusions of amines and gamma amino butyric acid on rumen fermentation parameters and food intake of steers offered grass silage. Anim. Feed Sci. Technol. 63:35-49.

Dawson, L. E. R. and C. S. Mayne. 1997. The effect of infusion of putrescine and gamma amino butyric acid on the intake of steers offered grass silage containing three levels of lactic acid. Anim. Feed Sci. Technol. 66:15-29.

Demeyer, D. I. and C. J. Van Nevel. 1975. Methanogenesis and integrated part of carbohydrate fermentation and its control. Digestion and Metabolism in the Ruminant The University of New England Publishing Unit, Armidale, NSW, Australia.

Fenderson, C. L. and W. G. Bergen. 1976. Effect of excess dietary protein on feed intake and nitrogen metabolism in steers. J. Anim. Sci. 42:1323-1330.

Fusi, E., L. Rossi, R. Rebucci, F. Cheli, A. Di Giancamillo, C. Domeneghini, L. Pinotti, V. Dell'Orto, and A. Baldi. 2004. Administration of biogenic amines to Saanen kids: Effects on growth performance, meat quality and gut histology. Small Rumin. Res. 53:1-7.

Gagen, E. J., P. Mosoni, S. Denman, R. Jassim, C. McSweeney, and E. Forano. 2012. Methanogen colonisation does not significantly alter acetogen diversity in lambs isolated $17 \mathrm{~h}$ after birth and raised aseptically. Microb. Ecol. 64:628-640.

Getachew, G., E. J. DePeters, and P. H. Robinson. 2004. In vitro gas production provides effective method for assessing ruminant feeds. Calif. Agric. 58:54.

Han, S.-K., S.-H. Kim, and H.-S. Shin. 2005. UASB treatment of wastewater with VFA and alcohol generated during hydrogen fermentation of food waste. Process Biochem. 40:2897-2905.

Hane, B. G., K. Jager, and H. G. Drexler. 1993. The pearson product-moment correlation coefficient is better suited for 
identification of DNA fingerprint profiles than band matching algorithms. Electrophoresis 14:967-972.

Kim, S. H., M. J. Alam, M. J. Gu, K. W. Park, C. O. Jeon, J. K. Ha, K. K. Cho, and S. S. Lee. 2012. Effect of total mixed ration with fermented feed on ruminal in vitro fermentation, growth performance and blood characteristics of Hanwoo steers. Asian Australas. J. Anim. Sci. 25:213-223.

Krizek, M., P. Kalac, and J. Peterka. 1993. Biogenic amines in silage. 3. The occurrence of six biogenic amines in farm-scale grass and maize silages. Arch Tierernahr 45:131-137.

MacDonald, K. A., J. W. Penno, E. S. Kolver, W. A. C. Carter, and J. A. S. Lancaster. 1998. Balancing pasture and maize silage diets for dairy cows using urea, soybean meal or fishmeal. In Proceedings of the New Zealand Society of Animal Production. New Zealand Soc. Anim. Prod. 58:102-105.

Mamuad, L., S. H. Kim, C. D. Jeong, Y. J. Choi, C. O. Jeon, and S.-S. Lee. 2014. Effect of fumarate reducing bacteria on in vitro rumen fermentation, methane mitigation and microbial diversity. J. Microbiol. 52:120-128.

Mao, S. Y., G. Zhang, and W. Y. Zhu. 2008. Effect of disodium fumarate on ruminal metabolism and rumen bacterial communities as revealed by denaturing gradient gel electrophoresis analysis of $16 \mathrm{~S}$ ribosomal DNA. Anim. Feed Sci. Tech. 140:293-306.

Martin, S. A. and M. N. Streeter. 1995. Effect of malate on in vitro mixed ruminal microorganism fermentation. J. Anim. Sci. 73:2141-2145.

Motoi, Y., Y. Obara, and K. Shimbayashi. 1984. Changes in histamine concentration of ruminal contents and plasma in cattle fed on a formula feed and rolled barley. Nihon Juigaku Zasshi 46:309-314.

Muyzer, G. and K. Smalla. 1998. Application of denaturing gradient gel electrophoresis (DGGE) and temperature gradient gel electrophoresis (TGGE) in microbial ecology. Antonie van Leeuwenhoek 73:127-141.

Nübel, U., B. Engelen, A. Felske, J. Snaidr, A. Wieshuber, R. I. Amann, W. Ludwig, and H. Backhaus. 1996. Sequence heterogeneities of genes encoding 16S rRNAs in Paenibacillus polymyxa detected by temperature gradient gel electrophoresis. J. Bacteriol. 178:5636-5643.

Offner, A., A. Bach, and D. Sauvant. 2003. Quantitative review of in situ starch degradation in the rumen. Anim. Feed Sci. Technol. 106:81-93.

Phuntsok, T., M. A. Froetschel, H. E. Amos, M. Zheng, and Y. W. Huang. 1998. Biogenic amines in silage, apparent postruminal passage, and the relationship between biogenic amines and digestive function and intake by steers. J. Dairy Sci. 81:21932203.

Plaizier, J. C., D. O. Krause, G. N. Gozho, and B. W. McBride. 2008. Subacute ruminal acidosis in dairy cows: The physiological causes, incidence and consequences. Vet. J. 176:21-31.
Russell, J. B. and R. L. Baldwin. 1979. Comparison of substrate affinities among several rumen bacteria: A possible determinant of rumen bacterial competition. Appl. Environ. Microbiol. 37:531-536.

Russell, J. B. and P. J. Van Soest. 1984. In vitro ruminal fermentation of organic acids common in forage. Appl. Environ. Microbiol. 47:155-159.

SAS. 2002. SAS/STAT. Statistical analysis systems for windows. Release 9.1. SAS Institute Inc., Cary, NC, USA.

Seo, J. K., J. Yang, H. J. Kim, S. D. Upadhaya, W. M. Cho, and J. K. Ha. 2010. Effects of synchronization of carbohydrate and protein supply on ruminal fermentation, nitrogen metabolism and microbial protein synthesis in Holstein steers. Asian Australas. J. Anim. Sci. 23:1455-1461.

Snyder, L. R., J. J. Kirkland, and J. L. Glajch. 1997. Practical HPLC Method Development. John Wiley \& Sons, Inc. Hoboken, NJ, USA.

Steidlova, S. and P. Kala. 2002. Levels of biogenic amines in maize silages. Anim. Feed Sci. Technol. 102:197-205.

Stone, W. C. 2004. Nutritional approaches to minimize subacute ruminal acidosis and laminitis in dairy cattle. J. Dairy Sci. 87:E13-E26.

Tabaru, H., E. Kadota, H. Yamada, N. Sasaki, and A. Takeuchi. 1988. Determination of volatile fatty acids and lactic acid in bovine plasma and ruminal fluid by high performance liquid chromatography. Jpn. J. Vet. Sci. 50:1124-1126.

Thauer, R. K. 1998. Biochemistry of methanogenesis: A tribute to Marjory Stephenson: 1998 Marjory Stephenson Prize Lecture. Microbiology 144:2377-2406.

Tveit, B., F. Lingaas, M. Svendsen, and O. V. Sjaastad. 1992. Etiology of acetonemia in Norwegian cattle. 1. Effect of ketogenic silage, season, energy level, and genetic factors. J. Dairy Sci. 75:2421-2432.

van Beers-Schreurs, H. M. G., M. J. A. Nabuurs, L. Vellenga, H. J. K.-v. d. Valk, T. Wensing, and H. J. Breukink. 1998. Weaning and the weanling diet influence the villous height and crypt depth in the small intestine of pigs and alter the concentrations of short-chain fatty acids in the large intestine and blood. J. Nutr. 128:947-953.

van Kessel, J. A. S. and J. B. Russell. 1996. The effect of pH on ruminal methanogenesis. FEMS Microbiol. Ecol. 20:205-210.

Van Nevel, C. J. and D. I. Demeyer. 1977. Effect of monensin on rumen metabolism in vitro. Appl. Environ. Microbiol. 34:251257.

Van Os, M., J. P. Dulphy, and R. Baumont. 1995. The effect of protein degradation products in grass silages on feed intake and intake behaviour in sheep. Br. J. Nutr. 73:51-64.

Walker, J. A. and D. L. Harmon. 1995. Influence of ruminal or abomasal starch hydrolysate infusion on pancreatic exocrine secretion and blood glucose and insulin concentrations in steers. J. Anim. Sci. 73(12):3766-3774.

Williams, A. G. 1986. Rumen holotrich ciliate protozoa. Microbiol. Rev. 50:25-49. 